\title{
EL INFORME DE
} CENSURA

(CON NOTAS

EXPLICATIVAS DEL

AUTOR CENSURADO)*

Norman Manea**

"Wa libertad es algo más complejo y
más sutil que la violencia", escribió Thomas Mann.

Más sutil, ciertamente. Pero, con todas sus implicaciones patológicas, ¿es la Violencia un mecanismo tan simple y tan directo? ¿Debemos tomar el brusco derrumbe del poder comunista en Europa del Este, en 1989, como la prueba decisiva de que el coloso era simplista y precario, construido con arcilla y fácil de destruir?

Eso significaría olvidar demasiado rápidamente la coloración turbia y subterránea del sistema totalitario -y no hay que perder de vista que, incluso en el mundo sutil y complejo de.la libertad, existen rincones oscuros donde se pueden descubrir Violencia y Poder.

Los túneles secretos de la Securitate, revelados al mundo entero durante los combates de Bucarest, ofrecen una "visualización" espectacular del sistema de terror, de duplicidad y de corrupción por medio del cual la tiranía extendía sus ramificaciones a los círculos más amplios de la población; este aparato de intimidación era incomparablemente más

* Traducción de Silvia Pasternac.

${ }^{* *}$ Escritor de origen rumano.

${ }^{1}$ En una carta a Erika y Klaus Mann, diciembre de 1938, Letters, p. 290. 
Norman Manea

complejo y siniestro que aquel representado por los grupos de fanáticos que hemos visto, durante el levantamiento, listos a pelear hasta la muerte, y por todos los medios necesarios, para salvar su pellejo. En un país que cuenta aproximadamente con cuatro millones de mienbros (oportunistas) del partido en el Poder, y que posee una vasta red de informadores dentro de todas las instituciones (incluso en los edificios de habitación), es difícil creer que el combate que tuvo lugar en Rumania a fines de 1989 sólo opusiera -como la prensa lo proclamaba- a la Securitate por un lado, al Ejército y el Pueblo por el otro. Basta con recordar que el número de miembros de la Securitate tanto en el ejército como en el pueblo era enorme... Las armas del Poder, en ese terrible enfrentamiento por la libertad, no fueron solamente esas que se vieron y se oyeron, sino también muchas otras: eran más numerosas, más sutiles e incluso más crueles, si se considera que las armas menos visibles tienen los efectos más duraderos, más profundamente clavados en la mentalidad de la sociedad. Será mucho más duro reponerse del largo y complejo proceso de degradación impuesto por aquellos que estuvieron recientemente en el poder, que resolver los múltiples problemas administrativos, económicos y materiales, en el sendero frágil y complejo hacia la democracia y la libertad.

La censura -la policía secreta del Lenguaje- fue, durante cuarenta años, una de las armas más temibles del Poder.

Los censores comunistas (oportunistas en los decenios recientes) son percibidos frecuentemente en el Oeste como simples burócratas obtusos, fanáticos e incultos. Frecuentemente lo eran y así permanecían a veces. Pero el socialismo "desarrollado multilateralmente" ${ }^{2}$ refinó la Institución del Poder, y utilizó a personas instruidas, inteligentes y cínicas

${ }^{2}$ Nicolae Sceausescu inventó el concepto de Rumania como sociedad "desarrollada multilateralmente" en los años 70. Esta noción parecía anunciar el advenimiento dentro de una Rumania liberalizada de una sociedad socialista, de naturaleza probablemente superior al modelo estalinista del socialismo con su insistencia sobre la industria pesada. Este concepto fue ampliamente utilizado en la prensa oficial durante todo el desastroso periodo de atraso y de empobrecimiento de los años 80 , cuando Rumania se convirtió en una dictadura nacionalista, estalinista y "no europea". 
en esos puestos. Los métodos utilizados por la Institución evolucionaron igualmente durante los últimos decenios, volviéndose más "complejos" y más "sutiles". En pocas palabras, más pérfidos.

A finales de los años 70, la censura fue "abolida" en Rumania. El dictador mismo tuvo la idea de que la ambigüedad que había obtenido semejante "éxito" en la política extranjera rumana debía ser "desarrollada multilateralmente", en la política interior igualmente, a fin de evitar las objeciones (todavía tímidas) desarrolladas en la prensa extranjera contra el estalinismo represivo de Rumania.

La posición antisoviética de Rumania era utilizada como una prueba de supuesta "independencia", pero era también un pretexto para consolidar un Estado nacional-socialista bizantino que tomaba lecciones de tiranía de todas las fuentes, sin preocuparse por la geografía, la historia o la ideología. Este Estado mantuvo unas relaciones amistosas con Israel, y otras, muy estrechas, con los terroristas árabes. La política de "libre emigración" servía al viejo sueño nacionalista de "purificación" de la población haciendo entrar, al mismo tiempo, divisas fuertes en las arcas, ya que Israel y la República Federal Alemana pagaban por cada ciudadano liberado; al mismo tiempo, esta política le ganaba a Rumania el favor del Congreso estadounidense. Esta ambigüedad en su política extranjera atrajo hacia la dictadura rumana una sorprendente simpatía por parte del Oeste, como pudo verse por los gestos de cortesía de Charles de Gaulle, los panegíricos de Gerald Ford y Richard Nixon sobre la "libertad" reinante en Rumania, la marcada hospitalidad con la que el tirano fue recibido en las Cortes de Inglaterra y de Suecia, o también, entre otros numerosos ejemplos, las visitas y los estímulos frecuentes de los dignatarios alemanes occidentales. Ya fuera por ingenuidad o por cinismo, esto contribuyó imperdonablemente a intimidar todo intento de oposición en el interior del país.

Había llegado el momento, para la opinión pública rumana, débil, fácilmente manipulable y sin apoyo del extranjero, de ser definitivamente humillada y sofocada por el "genio" del Conducator. Iba a crear, en su República, una síntesis original del nazismo y del estalinismo -con algunos ingredientes artificiales de moda, a manera de condimento-bajo el nombre de "Nueva Democracia". 
Norman Manea

Una serie de medidas contradictorias fueron tomadas al mismo tiempo: por un lado, el aparato de vigilancia y de represión fue reforzado, mientras que por el otro, se instauraron algunas formas de gobierno aparentemente más "democráticas", cuyo fin principal era alejar el descontento público del partido comunista y de la Securitate, y llevarlo sobre las administraciones locales (estechamente dirigidas desde arriba), los colegas de trabajo, los vecinos, los conductores de autobuses repletos, los empleados de las tiendas vacías, etc. Esta especie de "sustitución" de la causa por los efectos produjo, a corto plazo, resultados aceptables para el Poder. ${ }^{3}$

El concepto de "sustitución" se generalizó. No solamente como táctica falaz de gobierno, sino también en ámbitos concretos, como los alimentos o la ropa: los productos auténticos fueron reemplazados progresivamente por sustitutos que no solamente tenían una calidad incomparablemente inferior, sino que muy frecuentemente eran simplemente falsos. Lo mismo ocurrió en materia de cultura, e incluso en las "acusaciones", un muy pequeño número de críticos del "hablar claro", pertenecientes a los más altos peldaños de la élite, estaba autorizado a decir lo que otros no se hubieran atrevido siquiera a soñar. Al mismo tiempo que comprometía a intelectuales y artistas honestos, ya aislados y marginados, esto brindaba al Poder una distracción calculada al dar al público una bocanada de aire que sólo era un simulacro más: la "crítica", cualquiera fuera su tosquedad (y era frecuentemente muy primaria, perfectamente parecida al tema criticado), era automáticamente "dialéctica" y concluía invariablemente reafirmando una completa lealtad al Conducator, a su Estado y a su Ideología.

Los funcionarios pagaban impuestos "especiales" sobre todo tipo de servicios que habrían tenido que formar parte del deber de la administración, y un porcentaje mensual era retenido entonces de su hoja de

${ }^{3}$ En "The end of Communism in Poland and Hungary" (The New York Review of Books, 15 de junio de 1989), Timothy Garton Ash utiliza el término "poder" (the power)en el mismo sentido cuando escribe a propósito de Polonia: "casi nadie imaginaba que el profundo abismo entre 'el poder' y 'la sociedad', entre Jaruzelski y Walesa podía ser llenado tan rápidamente". 
pago para volverlos "copropietarios" de diferentes negocios en quiebra. Bajo la dictadura del proletariado, los trabajadores son los productores, los beneficiarios y los propietarios de todos los bienes, decía el Conducator con su "infalible sensatez".

La "Nueva Democracia" se extendió a estrategias de sustitución siempre nuevas. Enormes concentraciones de trabajadores (industriales, agrícolas, educativos y culturales) aclamaban periódicamente las "preciosas directivas" del Conducator concernientes a la fase siguiente del desastroso desarrollo del país, sobre el camino sonriente y sin fin hacia el comunismo. Existía una intención deliberada de extender el perímetro de la complicidad, hasta que la culpa estuviera por fuerza distribuida entre todos. Cada acto oficial tenía por lo menos dos aspectos, cuando no estaba, de hecho, "estratificado multilateralmente": uno era la representación cínica y grotesca de una farsa de "democracia popular", y el otro, el refinamiento sádico de los medios para engañar y aplastar a los ciudadanos.

Se volvió necesario, para dirigirse a la Milicia y pedirle permiso de ir al extranjero, obtener primeŕo "la aprobación" de los trabajadores: es decir, obtener una recomendación de un comité de empleados que, a su vez, era informado por un oficial de la Securitate (uno de ellos estaba apostado oficialmente en cada institución) de la respuesta que el candidato debía recibir de sus colaboradores.

En los medios, una extraña retórica combinaba viejos esloganes estalinistas con un lenguaje más elástico, comercializable en el Oeste, y particularmente con las viejas obsesiones nacionalistas de la extrema derecha rumana, por buscar el nuevo régimen nacional-socialista, confusamente, una legitimidad.

Una nueva generación de apparatchiks había aparecido entonces: jóvenes egresados de las universidades que habían hecho doctorados, e incluso estudiado en el extranjero, en algunos casos; su cínica duplicidad dio resultados. El partido esperaba (a veces con éxito) reemplazar la actividad intelectual real (que estaba cada vez más aislada, laminada y aterrorizada) con ese sucedáneo de la élite privilegiada. Se publicaban todo tipo de novelas y de poemas, en gran número de ejemplares, que "desenmascaraban" el abuso de los tiempos pasados o de épocas más 


\section{Norman Manea}

recientes; esos textos eran firmados por autores oficiales, bien pagados e hipócritas, cuyas "denuncias" eran propiedad de Estado incluso antes de ser escritas; los riesgos de estas "acusaciones", al estar cooptadas por el sistema, constituían una premisa de base para el vigoroso "debate dialéctico" en el cual participaban patéticamente. (Semejante "cooptación" era asunto de rutina, como cuando un abogado de la defensa reitera los argumentos del fiscal en aparente complicidad con él, pero en realidad con el fin de pervertir su sentido en favor de la defensa.) El éxito de estos "sustitutos" estaba asegurado por el hambre devoradora del público por cualquier tipo de pan, de carne, de libro, de ropa, de diversión o de información, por más falsificados que pudieran estar: no había nada más, e incluso estos ersatz eran propuestos con muy poca frecuencia, según los caprichos de la Familia reinante y de aquellos que estaban a su servicio.

A finales de los años 70 , un decreto presidencial abolió la prensa directa (la censura), una de las pocas instituciones eficaces del sistema.

El trabajo de este organismo debía ser retomado, naturalmente, por... los trabajadores. En la práctica, como antes, no se podía, evidentemente, imprimir siquiera un aviso necrológico o un anuncio comercial sin la aprobación de los sustitutos convenidos de los trabajadores. Los periódicos, los editores, las revistas, los impresores, debían organizar la censura por el sesgo de los consejos internos "especializados".

Ahora bien, la autocensura que se había ejercido durante decenios ya no satisfacía las expectativas de la burocracia del partido. La sed de verdad era tan grande, tan vastas y tan variadas las intrigas (que no sólo apuntaban al mal, sino también algunas veces al bien), que el número de textos perturbadores para las autoridades aumentaba constantemente.

Las medidas correctivas llegaron pronto. La censura fue "reforzada" con gran variedad de filtros intermedios, bajo los auspicios de un Consejo para la Educación y la Cultura socialistas y de su nuevo Servicio de Lectura. Las operaciones de esta oficina se duplicaron, se triplicaron, se multiplicaron y se diversificaron a medida que la "purificación" de los textos se revestía con nuevas justificaciones cada vez más absurdas. Los más escépticos pensaban incluso que la verdadera meta de la "la abolición" de la censura había sido el deseo el Poder de suscitar un descon- 


\section{EL INFORME DE CENSURA}

tento creciente y caótico, de manera que un número cada vez más grande de autores insatisfechos por el nuevo sistema "democrático" acabara por suplicar (por acusaciones, peticiones y otros medios democráticos) que se regresara a la vieja Institución central con sus métodos claros, lógicos y objetivos. En efecto, las tensiones crecientes de la vida cotidiana, en condiciones económicas catastróficas, estaban inevitablemente reflejadas con insistencia en textos cada vez más exasperados.

Esta era, entonces, la situación en Rumania en los años durante los cuales yo escribía mi novela $E l$ sobre negro. Tenía una cita de Thomas Mann colgada en la pared frente a mi escritorio: "La novela, a causa de su espíritu analítico, de su conciencia, de su actitud crítica innata, está obligada a huir de las condiciones políticas y sociales en las cuales la poesía puede seguir floreciendo tranquilamente en los límites sin ser molestada, dulcemente olvidada del mundo." 4 Thomas Mann escribió estas palabras durante un período de frenesí nazi, cuando los políticos del Führer insinuaban que sólo los prosistas alemanes, y no los poetas (esos detentores del "genio del alma alemana") habían escogido emigrar; mi elección de esta cita no era pura casualidad.

Al mismo tiempo que escribía, yo debía luchar contra lo imposible, alrededor y dentro de mí. Cada día decidía detenerme. "Mi conciencia crítica moral está en un estado de constante exacerbación y cada vez más se me vuelve imposible continuar con el juego, quizás sublime, de la escritura de una novela mientras no haya 'hecho un informe' y descargado mi corazón de su ansiedad, de sus percepciones, de su pena, así como de su cargamento de odio y de desprecio", escribía Thomas Mann durante los sombríos años de horror. ${ }^{5}$ Mi "juego" jugado en un tiempo y un lugar de horror era desgraciadamente inseparable de esa torturante necesidad de aligerar mi carga malsana, insoportable y sin embargo -de manera bastante extraña-estimulante por la resistencia que engendraba. iY sin embargo yo escribía! Una sola obsesión concentraba mis inquietudes: ique mi libro fuera "cooptado"! No debía ser bajo ningún caso cooptado por el sistema.

${ }^{4}$ Extracto de una carta a Eduard Korrodi, 3 de febrero de 1936.

${ }^{5}$ Extracto de una carta a Karl Kerenyi, 4 de agosto de 1934. 


\section{Norman Manea}

No fue una casualidad que yo colocara en el centro de mi novela la Asociación de sordomudos, organizada según "los principios del centralismo democrático" y dentro del espíritu del partido. ¿Era esa una versión "socialista" de la organización clandestina de los ciegos en la novela de Ernesto Sábato Sobre héroes y tumbas? Eso y más.

Era un intento de encontrar una metáfora (relativa, como debe ser toda metáfora) para el mundo de engaño y de mutilación, para la opresión oscura e infernal, la comunicación fragmentada, sibilina, mutilada, la frustración lúgubre, insoportable. Y para escapar a una realidad inmediata, claro está: los hospitales y los investigadores, las colas sin fin (para conseguir pan, guantes, jabón, gasolina, papel de baño), la enorme charada enfática, el frío, los miedos y las bromas, la indiferencia, el agotamiento y el terror, e incluso las propias angustias del novelista. El hombre y el pueblo. La desesperación, el amor, el miedo, la culpabilidad, la debilidad, los sueños y las pesadillas.

En la primavera de 1985 reuní afiebradamente $E l$ sobre negro a partir de cientos de páginas angustiadas. El libro formaba parte del plan de edición de ese año: yo pensaba que era mejor intentarlo antes de que fuera demasiado tarde.

A finales de noviembre, los editores todavía no habían recibido ninguna noticia del Servicio de Lectura del Consejo para la Educación y la Cultura socialista. La respuesta llegó en diciembre. Adiviné por la turbación de los editores que no era favorable. No se podía tener acceso al Informe del censor. Durante todo el tiempo que la censura había funcionado oficialmente (durante un cuarto de siglo a partir del final de la Segunda Guerra Mundial) estos informes habían sido considerados como secretos de Estado. Ahora que la censura había sido "abolida", estos informes se habían vuelto un secreto aún más secreto. ¿Informe del Censor? Los informes de la nueva Oficina de Censura ni siquiera estaban firmados, me enteré: estaban marcados simplemente con el número de identidad del lector (para uso de sus superiores, claro está). Los informes eran cuidadosamente conservados en los Archivos de la Verdad. La información podía transmitirse (oralmente, supongo) al director de la editorial o a algún otro funcionario digno de confianza; 


\section{EL INFORME DE CENSURA}

jamás al autor, quien era así incapaz de sostener un diálogo con la institución (inexistente) o el censor (invisible).

Recibí finalmente las pruebas del libro, con discretos símbolos escritos con lápiz sobre los pasajes y las páginas ofensivos. Alrededor del $80 \%$ del texto. Intenté descifrar las objeciones del censor. Eran manifiestamente demasiado numerosas; no parecía haber ninguna posibilidad de que yo las evitara todas. Lo inadmisible concernía tanto a palabras aisladas (por ejemplo colas, informador, comida, frío, café, senos, Dios, antisemitismo, dictador, sombrío, homosexual), como frases, capítulos enteros. No veía cómo se podía combatir a un censor tan concienzudo y hostil. Renuncié. El libro se quedó mucho tiempo sin tener ya un autor o un editor que se ocupara de él.

Comencé a sentir entonces los "efectos colaterales" de lo que se llama un "libro proscrito". Extractos de la novela, cuya publicación ya había sido aceptada por diversas revistas literarias, fueron retirados de ellas a último momento, cuando partían para la impresión. Artículos sobre el autor fueron igualmente suprimidos. La prensa comenzó a evitar su nombre, cada vez más sospechoso.

Releí nuevamente las pruebas. "Corregi" palabras y frases. Aquí y allá reemplacé algún pasaje. IInútil! Presentado por segunda vez, el manuscrito fue devuelto intacto al editor y al autor. Se me dio a entender que el censor consideraba mis "mejoras" como insignificantes e hipócritas. Frente a un callejón sin salida como éste, un autor debe tomar una decisión difícil. ¿Continuar, con terquedad, luchando palmo a palmo para que el libro sea publicado, haciendo tan pocas concesiones como sea posible, pero aceptando hacer compromisos con el censor? ¿O bien renunciar a la publicación?

Renunciar a la publicación supone otro tipo de esperanza: una esperanza de cambio político, la posibilidad de una aparición en el extranjero, o que la solución pueda ser dejada al cuidado de la posteridad. En 1985-1986, la única esperanza de un deshielo político era una "solución biológica": la muerte, por mucho tiempo esperada y por mucho tiempo retrasada del Conducator. ¿Qué posibilidad había de enviar un manuscrito al exterior, siendo que los contactos con el extranjero eran ilegales y la vigilancia absoluta? ¿Y quién iba, en ese caso, a publicar una larga 
Norman Manea

novela cifrada de una literatura casi desconocida? En cuanto a la posteridad, no solamente es una cantidad incalculable, sino que es también, paradójicamente, una "propiedad de Estado". Uno nunca puede tener la seguridad de haber encontrado un escondite seguro para un manuscrito a propósito del cual la Oficina de Censura (y sus asistentes de la Securitate) ya sabía demasiado. Muchos intelectuales creen seriamente que toda la "verdadera literatura" de un período sombrío como éste, está depositada en las cajas fuertes de la Securitate. Será seguramente obligatorio, para los historiadores de esta época de horror (en la prensa oficial, "los años ilustrados") consultar la inmensa biblioteca de manuscritos confiscados, almacenados en reductos, cajas fuertes y sótanos del Consejo Superior de la Seguridad.

Al comienzo de 1986, el editor dio el primer paso hacia el descubrimiento de una solución posible. Era el mismo método adoptado por el poder con respecto a sus sujetos y a sus propias instituciones: la de la sustitución.

El editor formaba parte de esas raras personas de su profesión que, en circunstancias de terror absoluto, todavía intentaban publicar buenos libros, incomodando al Poder, a pesar de las presiones ejercidas por la 16 censura. Los editores, bien conocidos por los escritores, perseveraban en una especie de resistencia intelectual cada vez más desesperada y agotadora.

No me será fácil olvidar la mañana de enero de 1986 en que acompañé al director de la editorial a una florería. Llevó la maceta de flores en sus brazos hasta el edificio donde vivía alguien cuya ayuda había decidido pedir, después de larga vacilación. Era una persona con experiencia, que constituía una autoridad en el "campo" de la censura, y que todavía podía jugar el papel de lector "exterior" (consultante). Así, el editor buscaba entonces un "sustituto". Un re-lector "civil", pero que se especializara en las zonas oscuras de la censura. Un antiguo censor -eran bastante numerosos-con suficiente inteligencia y prestigio para firmar un informe en regla, con modificaciones aceptables por la Oficina de Censura, pero sin que la Oficina de Censura (inexistente) esté implicada oficialmente. El sucedáneo de informe, firmado por un individuo, podía ser mostrado al autor; esto parecía una posibilidad real de salir del callejón sin salida. 
En marzo de 1986 recibí una "copia de trabajo" del informe de sustitución. Lo leí con mucha excitación. Nunca me había sido dado leer informes de censura. Frases y capítulos enteros habían sido cortados de muchos de mis libros y de artículos críticos relacionados con ellos. Había ocurrido incluso con un libro ya impreso: la distribución había sido retrasada, y el volumen fue "reestructurado" con la supresión de algunas de sus historias. Pero era la primera vez que tenía un documento de ese tipo en mis manos.

Claro, era un secreto de Estado desfigurado, pero eso me dio una idea de lo que debía ser el informe "original" en los Archivos de la Verdad. La forma "literaria" me sorprendió tan poco como me tranquilizó. Estaba seguro de que el censor verdadero podía haber escrito de manera aun más "sutil".

Estaba asustado. Si; ipura y simplemente asustado! Esas líneas donde las similitudes entre el nazismo y la dictadura rumana actual, que yo había puesto en mi novela, estaban "descifradas"; sí, asustado. Tenía la sensación de que en cualquier momento la puerta podía abrirse y que me podían arrestar con base en esta "desfiguración". iY podía imaginarme seguro en los Archivos de la Verdad!

Pero, ¿y la duplicidad? ¿La duplicidad del autor, la duplicidad del lector? ¿La duplicidad del editor, la del mismo censor y de su sustituto? La duplicidad como un relevo de la comunicación (de la vida cotidiana y de la creatividad). El autor -aunque honesto- que escribe bajo un régimen totalitario quisiera que las artimañas, las alusiones, los códigos y las imágenes crudas, directas y brutales que pone en sus escritos alcancesn al lector (al que se dirigen, en una especie de triste solidaridad implícita) y sean ignorados por el censor. En este punto la duplicidad pesa particularmente sobre el escritor cautivo.

Días y noches duros, llenos de dudas, de miedo, de asco. La lucha para encontrar soluciones ambiguas que satisficieran y socavaran, sin embargo, sutilmente, las exigencias del censor. 
Norman Manea

\section{EL INFORME DEL CENSOR}

"El marco de los acontecimientos y de las situaciones presentadas en la nueva novela del escritor Norman Manea es el Bucarest de hoy, según ciertas afirmaciones precisas ('tres años después del terremoto') se trata del año 1980, pero los detalles de la sociedad sugieren el presente inmediato. Nos encontramos en una primavera que sigue a un invierno muy rudo, clima que agrava el malhumor de las personas y sus condiciones de vida; una primavera vigorosa y viviente en cuya atmósfera el deseo ardiente de vida y de amor se siente con un máximo de intensidad. Las personas son descritas en las actividades habituales de la vida cotidiana, esperando frente a los kioskos, caminando por las calles y los jardines públicos, apuradas y ansiosas, en los tranvías y los autobuses, hablando de sus necesidades, de sus problemas y de diferentes acontecimientos y situaciones de su lugar de trabajo.

Los destinos de algunos persọnajes.principales emergen a través de un gran número de escenas y una cantidad de glosa filosófica, histórica, moral y cultural; siguen los datos biográficos esenciales, al mismo tiempo que se dan nuevos elementos que sobrevienen en esta primavera y que aceleran el proceso de formación y de comprensión de sus propias preocupaciones. Anatol Dominic Vancea Voinov es el personaje que aparece más frecuentemente: es un antiguo profesor, actualmente empleado como recepcionista en el modes to Hotel Transit, tolerado por sus colegas y sus superiores a causa de sus conocimientos en lenguas extranjeras. Inteligente, receptivo, culto, Dominic, quien, en su adolescencia fue un estudiante bien educado, tímido y serio, se volvió luego perezoso, atolondrado, indiferente, despreciativo, y se burla de todo el mundo; utiliza un vocabulario violento, tiene una forma de vestir chocante y profiere discursos eruditos con el fín de intimidar a sus colegas, quienes son incultos, personas simples que sólo se interesan en cosas fútiles.

Sentimentalmente, Dominic, quien ha alcanzado la cincuentena, es solitario, triste y está fatigado. Descontento y desengañado, intenta resistir a una vida de conformimismo y de compromiso por medio de una supuesta indiferencia y por la caricatura. Su destino estuvo marcado por algunas desgracias sufridas por los miembros de su familia en 1940: un 


\section{EL INFORME DE CENSURA}

juicio que se entabló contra ellos sin razón y luego la desaparición de su padre (¿asesinato o suicidio?), tras haber recibido una carta de amenaza formulada en el estilo de los manifiestos de la Legión. ${ }^{7}$ La familia se dispersa entonces (le hermana emigra hacia Israel, el hermano hacia Argentina, la madre muere en la miseria).

Las investigaciones que emprende ahora Dominic, en esta primavera vivificante, aclaran las circunstancias del drama que atravesó a toda la familia: la carta de amenaza que había llegado en un sobre negro, había sido enviada por un joven enamorado de su hermana que después se esconde durante cuarenta años en una institución para sordomudos. Pero donde sea que vaya no puede comprender su pasado ni sus sentimientos de culpabilidad y sus causas profundas. Es, en lo esencial, una advertencia que incita a comprender que los pequeños acontecimientos pueden tener grandes efectos sobre las personas en condiciones de violencia, de miedo y de terror.

Otro personaje importante es Matei (Mauriciu) Gafton, un periodista retirado. Entusiasta durante el período del dogmatismo, ${ }^{8}$ ahora Gafton trata de compensar las "mentiras" que escribió enviando peticiones anónimas y cartas que señalan a las autoridades las irregularidades, las insuficiencias y las inexactitudes, tratrando con esto, en tanto que "editor voluntario" colocado en el "centro de los acontecimientos", "en contacto con todo lo que dice y piensa el hombre de la calle", de mostrar "la verdad" y de trar la "justicia". Al mismo tiempo, estudia en la biblioteca los diarios del período fascista, la dictadura de Antonescu, ${ }^{9}$ con la intención de escribir un ensayo que demuestre "el asco de antes y durante la guerra y el entusiasmo y la exageración de la postguerra" (p.31). Este personaje representa también otra hipóstasis de la metnira vivida: cambió su nombre durante la guerra, tomando el de su mujer, que tenía un hermano en

${ }^{7}$ Se refiere a organizaciones fascistas rumanas, como "La legión del Arcángel Miguel", después "Guardia de Hierro".

8 La propaganda del partido utiliza este término para referirse al período estalinista.

${ }^{9}$ Ver nota 11. 


\section{Norman Manea}

la Legión y era buscado. De esta manera, él, "el infinitamente perseguido, rechaza la persecusión de los otros" (p. 52, 56, 218).

El antagonista de estos dos personajes es Ianuli, idealista típico, revolucionario coherente, personaje completo, con una vida ejemplar. Originario de Grecia, de una familia acomodada, Ianuli rompió todos sus lazos, abandonó su carrera universitaria y combatió en la montaña, arma en mano. ${ }^{10}$ Después de la guerra viene a Rumania y conserva, al pasar los años, las convicciones de su juventud, su "fe" pura. Privado de toda relación con su generación e incapaz de adaptarse a la nueva situación, lejos de su familia y de su casa, sin desear regresar puesto que todo ha cambiado allá, Ianuli se siente cada vez más alienado, marginado. Enfermo y resignado, traicionado por su mujer, abandonado por todos, sufre intensamente la psicología del aislamiento.

Otro dos personajes son de primera importancia para entender la significación de los argumentos de la novela.

Uno es el Dr. Marga, alma práctica y racional, confesor y consejero de aquellos que lo rodean, presencia que les es necesaria cuando intentan aclarar sus preocupaciones y sus dudas.

El otro es Irina Radovici, a través de la cual son abordados los problemas del amor. Irina, arquitecta, competente y sensible, fue empujada por los acontecimientos de su vida a los márgenes de la sociedad. Su curso universitario se interrumpió muchas veces, no fue autorizada a pasar su examen final, tuvo dos matrimonios fracasados; trabaja ahora para el periódico de la asociación de sordomudos y trata de encontrar las fuerzas para salirse de una historia de amor sin perspectiva, que la tiraniza. Su búsqueda de un equilibrio, que parece encontrar al final de la novela, la lleva a huir continuamente de sí misma y de aquellos que la rodean, y a una oposición exasperada que le roba toda su energía, a un retiro sin descanso y opresivo de la sociedad, a una austeridad dominada por las dudas y las preocupaciones.

Todas estas preocupaciones son de hecho referencias para la novela que planea escribir un extraño escritor, Mynheer, quien se encuentra

${ }^{10}$ Se refiere a la guerra civil griega en los años que siguieron inmediatamente a la Segunda Guerra Mundial. 


\section{EL INFORME DE CENSURA}

actualmente en un callejón sin salida. Necesita estar inspirado, trabajar, pero está aislado y apático; está obsesionado por la idea de escribir la verdad sobre la vida y la gente, de no evitar compromisos, pero al mismo tiempo está lleno de impotencia, de dudas y de falta de coraje. Los personajes del libro, las hipóstasis de Mynheer (sus "sustitutos"), aparecen en el libro como los intérpretes de diferentes actitudes, estados de ánimo, formas de existencia, que el autor encuentra en su propia vida ("sustitutos" para esas categorías de personas). Mucho espacio de la novela está consagrado a los vagabundeos de Mynheer en las calles de Bucarest, a sus conversaciones con diferentes personas, particularmente con Toma (un personaje ambiguo, administrador e investigador), y a sus reflexiones sobre temas sociales, morales, culturales y artísticos. La finalidad de estas digresiones es volver explícitas muchas ideas y tesis que forman la base de los argumentos presentados en la novela: la necesidad de hacer una elección clara (elegir entre el "Sí" y el "No"), de vivir sincera y auténticamente y de condenar la falta de autenticidad en la sociedad, el amor y el arte; las relaciones entre la verdad y la belleza, ente el contemplativo y el racional, entre el ideal y la acción, etc.

Una revisión estructural del libro será necesaria antes de su publicación, con el fin de aclarar la significación ideológica de algunos temas y de algunos problemas, y con el fin de permitir el pleno desarrollo de los personajes principales, de su aptitud para integrarse en la sociedad, de la atmósfera y de las determinaciones exteriores de su existencia.

\section{Algunas sugerencias:}

1. La idea de un peligro de resurgimiento de las fuezas del mal del período fascista en las condiciones actuales, está presente en toda la novela, lo que motiva la recomendación de no olvidar nunca las graves consecuencias de este período, de no admitir bajo ninguna forma la reaparición de tales tendencias.

Precisamente por esta razón, esta idea debe tratarse con más claridad.

En la forma actual de la novela, esta recomendación puede ser entendida en referencia a la situación en nuestro país. Matei Gafton trabaja 


\section{Norman Manea}

en su estudio del período de la Legión y de la dictadura de Antonescu ${ }^{11}$ con el fin de despertar la memoria de "aquellos que olvidan facilmente". Está preocupado y escandalizado por el peligro de un retorno al pasado, por la tendencia hacia una "amnistía, o hacia un simple camuflaje del mal", por la tentación de "hacer del prestigio literario una plataforma de lanzamiento o de relanzamiento del mal", fomentando con esto "cálculos enteramente extraños a la literatura" (p. 17); percibe los errores de los editores, quienes al explotar a nuestros clásicos "retoman ideas retrógradas" expresadas por éstos en sus vidas públicas, defendiendo "la creatividad literaria del valor", 12 "disimulando" o "deformando" al mismo tiempo la verdad sobre su compromiso durante este período. Esta tendencia será la expresión de "la concepción del nuevo dogmatismo" en el problema de la "cooptación de los grandes valores espirituales del pasado" ( $\mathrm{p}$. 48). Hay referencias repetidas al saber de los medios en relación con la devastación del departamento de una mujer sola con el pretexto de que tenía animales allí. La gravedad de este violento "desvio de la atención", que se desarrolla en pleno día y bajo la mirada impasible de la Milicia, está acentuada (p. 10, 15, 32, 34, 38, 39, 41, 47, 59, 60, 111, 219, 331). Hacia el final del libro nos enteramos de que toda la familia de la víctima -la Sra. Venera- fue incinerada en los hornos crematorios de Hitler. Reconstruyendo la atmósfera de los años de antes y durante la guerra, Matei Gafton sólo retiene de los periódicos los títulos que muestran la instauración y la organización del mecanismo de la opresión durante el período de la dictadura de Antonescu, buscando pruebas de la idea de que esa atmósfera pudo haber sido generalmente favorable a la institución del fascismo ${ }^{13}$ (p. 13, 14, 30-31, 39 y 47). La escena en la cual

${ }^{11}$ Primero alineado con la Legión, el general Ion Antonescu reprimió a la Guardia de Hierro cuando ésta trató de tomar el poder. La dictadura militar de derecha de Antonescu duró hasta 1944, cuando Rumania, bajo la ocupación soviética, firmó el armisticio y cambió de bando para unirse a los Aliados.

${ }^{12}$ Se refiere a la reimpresión de algunos textos violentamente nacionalistas de los clásicos rumanos.

${ }^{13}$ La propaganda del partido se niega a reconocer la gran preferencia con que contaron los movimientos de derecha y fascistas entre el electorado, antes de la Segunda Guerra Mundial. 


\section{EL INFORME DE CENSURA}

Dominic se imagina a sí mismo encontrándose con fantasmas del pasado, personas asesinadas o desaparecidas, incluido su padre, se repite varias veces. Es éste un acercamiento parcial, ya que había un poderoso movimiento antifascista ${ }^{14}$ en nuestro país, así como una inteligencia con espíritu democrático, y ya que algunas medidas fueron tomadas por el propio Estado ${ }^{15}$ para salvar vidas humanas cuando la deportación hacia los campos de Hitler. El intercambio de opiniones entre Ianuli y el doctor Marga al final del libro, sobre la psicología del aislamiento, sobre las distinciones que hacen las personas comunes sobre aquellos que tienen otras nacionalidades cuando se presentan problemas o cuando hay penuria (p. $428,433,444-456$ ) reduce la significación del libro. Dada la masa de problemas explorados a lo largo de la obra, la idea esencial del libro, su mensaje ideológico, encontraría mejor expresión y estaría enriquecido con un alegato para el compromiso, para la integración en una sociedad estable, auténtica y por el desarrollo positivo de los personajes en esta dirección.

2. La novela presenta una visión parcial, mảrcadamente negativa de la vida cotidiana y del clima social y moral en el que evolucionan los destinos de los personajes. Algunos rasgos que contribuyen a esto:

a) Además de los personajes centrales, que son en su mayoría solitarios incapaces de adaptarse, hay entre los personajes secundarios algunos tipos de categorías y de situaciones sociales significativos. El tecnócrata cínico y oportunista desprovisto de todo principio o de toda conciencia moral, que tiene también una función dentro de la jerarquía social ( $p$. 95-98). En el lado opuesto de éste, el brillante ingeniero que después de recibir su diploma como primero de la clase, rechaza del gobierno

${ }^{14}$ Uno de los lugares comunes más vivos de la propaganda es exagerar el movimiento antifascista (en realidad débil) en Rumania, antes y durante la guerra.

${ }^{15}$ Con el fin de ganarse la simpatía del Oeste, el partido intentó efectivamene, durante los últimos decenios, retocar la imagen de la derecha rumana, en particular de su "actitud humanitaria" hacia las minorías. 


\section{Norman Manea}

central las proposiciones que se le hicieron y queda como un ingeniero anónimo y común en un pequeño trabajo en la provincia con el fin de evitar hacer "concesiones". También hay dos adolescentes a quienes nunca faltó nada, amorales y repelentes: el muchacho, alcohólico y encerrado en un hospital psiquiátrico, utiliza un vocabulario extremadamente vulgar (p. 83-88), mientras que la muchacha, abordada en el metro por un borracho, acepta su proposiciones (p. 108-109).

b) Las caracterizaciones morales, las relaciones personales, la atmósfera en los lugares de trabajo -en el grado en el que esto aparece en la novela-son todas completamente odiosas. El personal del Hotel Transit está compuesto únicamente por personajes incultos y primitivos, holgazanes, calumniadores, propaladores de rumores, informadores y amantes de las propinas ("cucarachas asalariadas") que cubren sus maquinaciones preparando cuartos para tdoo tipo de personajes importantes que realizan allí sus citas amorosas (p. 70-78, 231-252). Cada vez que doctores, enfermeras u hospitales se mencionan, hay siempre alguna insinuación de tratos especiales, gratificaciones, inmoralidad ("estafas que formaban parte desde hacía ya algún tiempo de esta actividad, que en otras épocas 24 fue noble"). Ejemplos: p. 86, 317, 327, 361, 373.

La conversación entre dos oficiales, oída en el parque por Irina, revela el mecanismo según el cual una asamblea para una elección del partido se planifica en una fábrica, y la inmoralidad general (p. 92-94).

c) Siguiendo los vagabundeos cotidianos de los personaes, así como utilizando gran número de escenas y de capítulos independientes, la novela presenta una imagen de la vida actual, principalmente en Bucarest, bajo sus aspectos negativos, depresivos y grotescos: suciedad, calles malolientes, personas cansadas, agresivas, groserias, autobuses y tranvías repletos, colas fuera de las tiendas, polvo, oscuridad, etc. La estructura de la novela permite un examen de estos elementos que componen el fondo social, el contexto que influye y determina el estado de ánimo de los personajes. La imagen de Bucarest en los bellos días de la primavera podría proporcionar gran número de escenas y de personajes, en un marco luminoso y vivificante. Sin estas escenas, la novela es defectuosa: 


\section{EL INFORME DE CENSURA}

es parcial y esquemática. Mejorar el texto por medio de la eliminación de ciertos capítulos, comentarios y excesos en el campo de la caricatura, de la ironía y de lo grotesco, enderezándolo al mismo tiempo por medio de la inserción de algunos pasajes afirmativos y positivos contribuiría al equilibrio y a la mejor expresión de la visión del libro como conjunto.

\section{Aclaraciones necesarias sobre la significación de los personajes y del mensaje del libro.}

* Dominic: Debe comprender al final que vivir en la mentira y en la indiferencia no es una solución: debería al menos dejar vislumbrar una pequeña posibilidad de integración en la sociedad (después de todo, es el personaje principal).

* Ianuli: Es un personaje muy importante (a pesar de tener tan sólo un pequeño papel) en cuanto al significado del argumento (los problemas de los extranjeros, la psicología del aislamiento, así como la suerte de los revolucionarios profesionales que combaten para defender su ideología). Debería dejarse claro que su posición de revolucionario rechazado hacia el margen de la sociedad, se debe al hecho de que no ha captado los nuevos problemas y las nuevas necesidades del período que siguió al combate como tal (esto debe ser explicado muy explícitamente). Las conversaciones del final y la narración a lo largo de la novela en lo que se refiere a la situación de Ianuli deben ser revisadas, ya que, en su forma actual, su historia podría ser entendida como implicando el fracaso de la lucha, de la participación activa en la construcción de la última fase del socialismo, y como significando al mismo tiempo la existencia de una oposición irreductible entre el ideal revolucionario y la lucha o la acción (ver en particular p. 424). 


\section{Norman Manea}

* Minheer: Sería necesario que tuviera más fuertemente el papel de un "raisonneur" ${ }^{16}$ que ayude a aclarar el significado de los debates teóricos y de las reflexiones filosófico-sociológicas y morales; debería defender la importancia del retorno al curso natural de la vida, a una estabilidad bien enraizada, y la de la adopción de una forma de comportamiento constructiva, variada, no egoísta, etc. El tema de los "sustitutos", que aparece en numerosas ocasiones, y no solamente en aquellas que conciernen a las relaciones entre los personajes y el escritor o los caracteres y su modelo vivo real, debe volverse más claro. En algunas fórmulas, la idea de que vivimos en la mentira es, sin motivo, extendida al conjunto de la sociedad. Por ejemplo: "un sustituto en un mundo de sustitutos... Cada uno descubría en sí mismo el concepto de la sustitución, ser otra cosa, escapar" (p. 181). "La mayoría de nosotros se convierte en otra cosa, si no en el opuesto de lo que somos realmente" (p. 184). "¿Qué son los sustitutos atascados en otros sutitutos más?" (p. 322). "Los sustitutos hacen las veces de verdad" (p. 305, 306, 310, etc.).

La idea del resurgimiento de las "fuerzas del mal", en las condiciones actulaes, y de la recurrencia de algunos fenómenos relacionados con el fascismo, con la patriotería, etc. "La advertencia".

* El problema no debería parecer reflejar la situación de nuestro país. Si éste está implicado, se debe mostrar que eso se aplica al mundo moderno (los medios muestran frecuentemente escenas de neofascismo, neonazismo, etc., y también marchas por la paz, que podrían ser vistas y comentadas por los personajes).

* Los libros no deberían preocuparse por el problema de la literatura. (Por ejemplo: ¿deben ser valorados Eminescu y Alecsandri? ${ }^{17}$ ¿Lo

16 "razonador", "discutidor" (n. de t.).

${ }^{17}$ Mihai Eminescu, Vasile Alecsandri: escritores rumanos clásicos. Hay algunas líneas antisemitas en sus obras. 
EL INFORME DE CENSURA

mismo con Rabbi Mozes R.? ${ }^{18}$ Hay allí los gérmenes de un gran escándalo.)

* Las investigaciones de Gafton en la prensa (en particular del año 1940) no deberían limitarse a los títulos sobre Rumania, y deberían incluir títulos que señalen las actividades del movimiento antifascista rumano y las protestas de la inteligentsia de espíritu democrático. Carol, e incluso Antonescu, no deberían ser colocados al mismo nivel que Hitler. $^{19}$

* Sería necesario tener cuidado para no dar la impresión de que hubo asesinatos, deportaciones, un verdadero holocausto aquí (la imagen de las filas de cadáveres evocada repetidamente por Dominic debe también ser revisada). No hay que olvidar que Rumania fue el único país que se negó a deportar a los judíos hacia los campos de exterminio nazis. ${ }^{20}$

* Reducir el número de escenas y de comentarios marginales sobre la nota roja extraída de la prensa rumana (irealmente?) concerniente a la devastación y el incendio del departamento de la mujer, por estar el pretexto de los animales tratado como un desvio de la atención. No habría que hacer creer que la agencia que aplica la ley -la Miliciatoleraría o "cubriría" semejante acto (no estamos en Alemania Occidental).

* Revisar el último capítulo del libro. El final debe ser cambiado. No debe ser un memorándum sobre la psicología del aislamiento y las

${ }^{18}$ Rabbi Mozes Rozen, diputado en el Parlamento comunista desde hace veinte años, protestó en estos últimos años contra la frecuente publicación de textos antisemitas de autores rumanos, clásicos y contemporáneos.

${ }^{19}$ El rey Carol II aceptó al principio colaborar con la Legión, y después reprimió el movimiento. Obligado a abdicar y abandonar Rumania en 1940, el rey cedió el poder a su heredero, el rey Michel (que tenía diecinueve años) y al general Antonescu.

${ }^{20}$ La propaganda del partido utilizaba esta mentira principalmente con el fin de ganarse la simpatía del Oeste. 


\section{Norman Manea}

manifestaciones nacionalistas. No es el único problema explorado en el libro. En su forma actual, eso reduce la significación del libro y desorienta a los lectores. (El libro estaría entonces reservado únicamente a los iniciados, y tendría un interés limitado.) La teoría de la psicología del aislamiento -tal como está presentada- puede reducirse en su esencia a las ideas siguientes:

- Los extranjeros, en cualquier contexto (normal o anormal), conservan sus características distintivas que "no deben ser ni negadas ni utilizadas contra ellos", es decir que es "una diferencia que debe ser aceptada".

- El resto (la nacionalidad dominante o mayoritaria) no considera a los extranjeros como sus iguales; en algunas circunstancias ("inquietud, crisis, angustia, impotencia") el egotismo, el mal y la estupidez "estallan y buscan liberarse" por actos y actitudes egoístas (lo mismo ocurre en las situaciones "de embrutecimiento general e institucionalizado" ???). Incluso en las condiciones normales de todos los días, algunos fenómenos indican que la interacción es relativa: "tienen ustedes los mismos derechos para participar en el mal, pero no para actuar contra el mal, no para estar comprometidos"; se consideraría como una "impertinencia que ustedes mismos intentaran enseñar a los que los rodean lo que es justo", el visitante "no tiene derecho a comprometerse demasiado..." (Ianuli es humillado cuando es visto con sorpresa, en el instituto donde trabaja, porque "él mismo" tuvo la valentía de comprometerse en una organización de perfeccionamiento). En general, se debe evitar teorizar sobre el problema de las nacionalidades. Tenemos documentos y principios con respecto a eso; el problema de las nacionalidades ha sido solucionado en nuestro país.

- Sería necesario también ser cuidadoso en la discusión de la cuestión del exilio como otra forma "de expatriación", emprendida bajo los efectos de un deseo natural de "libertad", deseo de escaparse del horror de la rutina y del "cautiverio". (El problema de la "libertad"...) Hay reflexiones indirectas sobre este tema a lo largo de todo el libro. 


\section{EL INFORME DE CENSURA}

Imagen negativa de la vida cotidiana.

Los capítulos y las escenas siguientes deben ser suprimidos:

* P. 63-67 (capítulo del avión y descripción del jefe de Estado-no tiene ninguna relación con el problema explorado en el libro).

* P. 83-84 (abreviar el capítulo con el adolescente alcohólico en el hospital psiquiátrico).

* P. 197-198 (la ley que reduce la escolaridad para los minusválidos "por razones de economía").

* P. 200-202 (extractos del diario de los sordomudos, presentación de los principios de organización de su asociación sobre la base del "centralismo democrático", su estatuto, etc.).

* P. 214-215 (comentarios insultantes y generalizadores sobre los estudiantes árabes en nuestro país).

* P. 206-208 (el mundo tal como lo ve Dominic).

* P. 70-80, 231-252 (escenas en el Hotel Transit que incluyen los "arreglos" para las personas importantes). Textos que incluyen también generalizaciones sobre los doctores.

Algunos personajes secundarios (¿y por qué no un personaje central?) que presenten una imagen positiva deben ser agregados. Por el momento sólo hay una escena de ese tipo, un grupo de niños pequeños. E incluso ellos parecen tristes, y están representados como autómatas reducidos a marcar el paso (p. 91).

El texto debe ser modificado en los pasajes siguientes:

*P. 20, 24, 27, 44, 54, 61, 90, 91, 96, 97, 98-100, 107, 114, 138-139, 217 , $235,263,264,266,316,326,343,346,348$ (imágenes de calles, suciedad, basura, oscuridad, colas, escasez de mercadería, personas cansadas, embrutecidas, caos, hambre).

* P. 12, 31, 89, 101, 268, 340 (referencias repetidas a la multitud apiñada en los transportes colectivos, p. 265: "El pasajero lucha o soporta. Luchar es soportar, nos enseñan nuestros historiadores locales"). 
Norman Manea

*P. 14, 77, 154, 194, 234, 245, 247, 302 (comentarios sobre la condición humana, como éste de las páginas 311-312: "La clase obrera no tiene nada que perder salvo sus desdichas").

* P. 8, 10, 57, 200-201 (caricatura del discurso político).

* P. 15 (robo de los paquetes de procedencia extranjera en el correo), p. 29 ("los tiranos de este siglo", refiriéndose a Hitler y a Stalin sin plantear distinciones entre ellos), p. 54-55, 263 (Securitate), p. 112, 353 (la ley concerniente a los perros), p. 196 ("el Año de los Minusválidos"), p. 222 ("enfermo de la historia"), p. 353-355 (bromas y chismes).

$$
* * * *
$$

¿Por qué estaba asustado al leer? ¿Era por el choque de descubrir, por primera vez, un tipo de "lectura" que hasta ahora solamente me había imaginado, sin haberme encontrado con él nunca? ¿Era el recuerdo inconsciente de un tipo de miedo más profundo, de los tiempos de los campos de concentración nazis o del terror estalinista? ¿O bien esos viejos recuerdos eran despertados por los rumores alarmantes que corrían en Bucarest, en aquella época, a propósito de la extraña muerte de algunos de mis colegas escritores, de casas de intelectuales y de artistas que habían sido registradas, $\mathrm{y}$-muy particularmente- a propósito de un ingeniero cuyo diario íntimo había sido descubierto y que había sido asesinado durante el interrogatorio de la Securitate?

Mi estado de sobre-excitación extrema me llevó a cometer un error. Esa misma tarde llamé a mi amigo a su casa. Expresé mi sorpresa y mi indignación. "¿Cómo? ¿Realmente se trata de eso? ¿Esta cosa supuestamente va a salvar mi libro? ¿Es ese el tipo de "ayuda" que tu milagrosa Persona nos prometió? Se supone que el texto debe ser literario y profesional -iParece el "nuevo estilo" ininteligible y pretencioso de los discursos de la Policía nuevo estilo!"

Hubo un largo silencio. Comprendí que había actuado muy imprudentemente. El teléfono de un "personaje dudoso" como yo estaba seguramente intervenido, al igual que el de una persona "oficial" como 


\section{EL INFORME DE CENSURA}

ese director. "Ese reporte de lectura contiene algunas sugerencias. Nadie te obliga aceptarlas. No veo por qué estás tan exasperado." Estas palabras era pronunciadas con calma, pero él parecía incómodo y nervioso. "Ven a verme mañana a mi oficina y me dices lo que has decidido", dijo brevemente, enérgicamente.

Nos vimos en su oficina, con el editor del libro, a la mañana siguiente. El tono del director era oficial, como debía serlo (todos suponíamos que había aparatos de escucha de la Securitate en algún lugar de la pieza), pero el autor no podía controlar sus nervios, incluso en esas condiciones.

Al final de la conversación, el editor se autorizó un momento de franqueza: "Usted sabe, cada día, sobre cada libro, nos dan notas, reportes e incluso quejas mucho peores que esta que le preocupa tanto. ¿Qué pasaría si nos asustáramos cada vez? No publicaríamos un solo libro..."

Sí, estábamos todos enganchados en el engranaje: sin la interacción dinámica de la duplicidad y de la obstinación, del rechazo, de las relaciones personales y de la tenacidad, nada podría hacerse, ninguno de los libros que habían logrado colarse entre las mallas apretadas de la red de la Policía del Lenguaje habría podido publicarse.

De acuerdo con el editor volví al combate que consistía en parecer aceptar las objeciones del censor, sin reconocerlas sinceramente.

El libro fue presentado nuevamente a la Oficina de Censura en abril de 1986. Mi condición era que esta vez no fuera leído por el mismo informador que la primera vez. Los comentarios marcados con lápiz sobre mi manuscrito eran seguidos por la demanda directa (pasada oralmente por el editor, claro está) de suprimir otros detalles concernientes a la Asociación de sordomudos y de modificar la "estructura" del personaje de Ianuli (el viejo revolucionario no decía una palabra en toda la novela) y del final, que sugería que ese personaje así como el femenino principal estaban a punto de morir o de suicidarse. Era la tercera serie de cambios que se me pedía que hiciera. Para terminar, el nuevo censor envió un mensaje de que la publicación estaría recomendada. Él debía ser convocado para una entrevista particular de una media hora con el vice-ministro encargado de ese "sector", y debía recibir personalmente la aprobación final. Ese era el ritual con los libros "problemáticos". 


\section{Norman Manea}

El libro apareció durante el verano de 1986. El director, ahogado por la presión de la Oficina de Censura, trataba de sacar beneficios sobre cada libro que publicaba. Por eso fue que lo imprimió en veintiséis mil ejemplares, tiraje excepcionalmente grande, al cual yo no había podido aspirar en veinte años de carrera de escritor publicado. El interés del público fue probablemente suscitado por los rumores que corrían cada vez que un libro era sostenido por la prensa y hecho picadillo por la Oficina de Censura: el libro se agotó en unos días en Bucarest. Mis amigos me aseguraron que en la versión de "sustitución" que había sido publicada, conservaba su agudeza crítica y su originalidad literaria. Las primeras reseñas, muy favorables, aparecieron en las revistas literarias del país al final de 1986. En diciembre del mismo año, me iba de Rumania.

El sucedáneo de informe me ayudó a hacer que mi libro se publicara. El censor me ayudó a publicar mi libro. Amigos próximos y enemigos desconocidos me ayudaron. Incluso el dictador ayudó a su manera, favoreciendo la ambigüedad (de la más siniestra especie, en función de sus posibilidades).

Soy un autor que no habría podido publicar durante el período estalinista. Mi generación creció durante el período torturado, angustiante (los "años iluminados") de la nueva dictadura. Nuestros libros se abrieron un camino en las tinieblas "iluminadas", constantemente cambiantes y cada vez más amenazadoras de este período confuso de asfixia creciente.

¿Estaba yo contento de ver mi libro frescamente publicado? Había sido un nacimiento difícil e inesperado. Mi bebé mutilado, aunque no fuera tal como yo me lo había imaginado, seguía siendo mío. Los lazos que nos unían, fuertes y asustados, correspondian a la época y al lugar donde habíamos intentado -luchando, mutilándonos, encadenándonos, defendiéndonos-resistir, subir juntos a la superficie.

El ersatz de Informe de censura no necesita probablemente ningún comentario. Tomando en cuenta el conjunto de la situación, con sus estratos de duplicidad, de la historia reciente y más antigua de este país ("la eternidad del lugar"), quizás debería empezar describiendo uno de mis pocos contactos con la Securitate. Un elegante joven de la "Sección 


\section{EL INFORME DE CENSURA}

de los Escritores" me ofreció un cigarrillo Kent (que en Rumania se fuman muy poco: se utilizan como moneda de cambio en el mercado negro); era bien educado y tranquilo, hablaba francamente. Durante más de una hora discutió sobre Faulkner. Y habló de él con competencia, debo reconocerlo. Esto confirma el éxito con el que la Securitate logró en los últimos decenios reclutar a algunos de los mejores alumnos de la Universidad. Pronto me dijo que había leído todos mis libros y que los había "comprendido", insistencia que evidentemente no me provocó ningún gusto. ("¿Pensaba usted, por ejemplo, que yo no había captado las alusiones a Piero di Cosimo y los pasajes sobre el Carnaval en el libro que usted escribió hace diez años?") Me sentía incómodo, me agitaba y escogía mis palabras; me sentía extraño, confuso, alienado, como una especie de sordomudo tartamudeante, dudando del mundo en el cual vivía, y de porqué vivía, contrastando violentamente con él, tan distendido, racional y cortés, tan abierto y bienintencionado. Sólo al final de esta incómoda entrevista me preguntó de pasada lo que pensaba de diversos debates en las revistas literarias, mi punto de vista sobre algunos "grupos" y algunas "líneas de pensamiento", etc. No, no ejerció presión, no era un interrogatorio, tampoco me obligó a confesar: era tan sólo una conversación, con una duplicidad medida, educada. Me dirigió una sonrisa irónica, superior, cuando rechacé su invitación a otra cita "amistosa"...

Para escribir un verdadero comentario sobre el Informe, necesitaría comentar todo un largo período, casi un cuarto de siglo, de confusión, de escritura cifrada y de opresión viciosa. Sólo con esto, tendría con qué hacer un grueso libro.

Pero no debo dejar de señalar al vuelo los "consejos preciosos" de ese sustituto, algunas menciones de la sorprendente confianza que tenía en la corrección del error. Un sentido "moral" del orden y de la proporción que llevaría nuevamente a aquel que está errando, progresivamente, al camino recto. Esta extraña criatura-imprudente, excesiva e incoherente (como lo prueba la obra extraña que produce) puede sin embargo ser cooptado: por eso el censor-profesor perspicaz repetía su lección pacientemente y con optimismo. Era la Educación misma, la Educación con sus consejos, sus reproches, sus amenazas, sus castigos y sus recompensas, 
Norman Manea

que nos siguen a todos, desde el nacimiento -en casa, en la escuela, en el ejército, en la iglesia, en el matrimonio, el Partido- hasta la muerte, y quizás incluso después, como nuestrọs descendientes conservan nuestra memoria. Los "buenos consejos" de las autoridades responden con frecuencia efectivamente a la necesidad de seguridad y de salud sentida por numerosos ciudadanos, tan necesarios para el Estado, en cuya educación éste invirtió tanto esfuerzo y tantas esperanzas.

No es función del arte revolcarse en la inmundicia por la inmundicia, no es nunca su tarea pintar a los hombres solamente en estado de decrepitud, tomar a cretinas como el símbolo de la maternidad, describir jorobados embrutecidos como representantes de la fuerza viril... El arte debe ser el servidor de lo sublime y de la belleza y promover así todo lo que es natural y sano. $\mathrm{Si}$ el arte no cumple esta tarea, entonces todo el dinero que se invierte en él es diplapidado.

Estas palabras sensatas no son las de mi censor (aunque sean muy semejantes a la opinión de todos los censores, donde sea, incluyendo al mío). No es tampoco una cita del senador Jesse Helms, con esa preocupación que tiene de no dejar que la obscenidad y la blasfemia se aprovechen del sostén que el Estado da al arte. No son tampoco las palabras del difunto Ayatolah que condenó al novelista Salman Rushdie a muerte. Tampoco son las reacciones de buen sentido de norteamericanos escandalizados de que se use una bandera de su patria como tapete en la entrada de una exposición, ni del número creciente de aquellos que defienden la abrogación del derecho de insultar a la bandera garantizado por la Constitución de los Estados Unidos. (Por supuesto, se aprende desde una edad muy temprana en pueblos de todas las nacionalidades a respetar la bandera de su país y quizás a quemar o a manchar de sus enemigos.) Son numerosos los que, en el presente o en el pasado, habrían podido pronunciar las palabras más arriba; de hecho, es Hitler quien las dice, en su fatal discurso de Nüremberg, en septiembre de 1935.

Después de descubrir esta cita de Hitler, no dejé de repetirla obsesivamente, por razones muy personales. Desde la infancia-los años nazis- 


\section{EL INFORME DE CENSURA}

fui una persona "desterrada". Después vino la pesadilla del estalinismo, los fracasos complicados de los descongelamientos siempre inciertos que le siguieron, y mi confuso deseo de libertad frustrado se hizo más profundo. Puedo plantearme la pregunta: ¿hasta qué punto estoy ahora calificado para gozar de la libertad y de sus privilegios fragmentarios?

El Informe me siguió a lo largo de mi penoso viaje cuando abandoné Rumania. Leí de nuevo el manuscrito original de la novela, comparándolo con el refrito (de sutitución) publicado. ¿Cooptado por el sistema? No, no creo que ese libro haya podido ser cooptado por la fraseología dialéctio-cínica del Dictador. Truncado o no, alterado o no, "ellos" no podían cooptar el texto: pareciera que gané sobre ese punto.

¿Pero podía, de una u otra manera, ser cooptado en su conjunto? $\mathrm{Ni}$ las críticas favorables que habían comenzado a aparecer en Rumania cuando me fuí, ni siquiera un comentario admirativo en Le Monde, que afirmaba que El sobre negro prolongaba la tradición de Kafka, podían servir de contrapeso a la irritación que yo sentía releyendo el libro. No era la desaparición, en la versión editada, de algunos sombríos detalles de la vida cotidiana lo que me exasperaba, ni el "suavizamiento" de numerosos pasajes. Era el efecto realmente perverso de toda esa codificación. El oscurecimiento. El exceso y la opacidad estilísticos. La desvitalización, los rodeos, el estropicio. La manera como la Oficina de Censura seguía siendo la ganadora, como por una acción de efecto retardado y un control a distancia, incluso si parecía que yo los había engañado y vencido. El escritor que se creía tan "comprometido" estéticamente, descubría todas las páginas, todos los pasajes, todos los capítulos que habían sido corrompidos por los mismos artificios que había utilizado (frecuentemente con un sentimiento de triunfo), como una parada contra la Oficina de Censura. Y se preguntaba si se trataba solamente ahí del descontento habitual de todo autor frente a una obra terminada desde hacía tiempo, o si era más que eso...

Un amigo me escritor de Bucarest el 21 de enero de 1990: "¿Qué durará, de toda la literatura que hemos escrito, de toda la literatura escrita en estos últimos cuarenta años? ¿Acaso se trata de una literatura contextual, que sólo tiene un valor circunstancial, no solamente cuando explota los hechos históricos, sino incluso cuando los ignora? Soy un 


\section{Norman Manea}

pesimista, como sabes: podría ser que todo esto no sea más que un 'paréntesis' en la historia, desporvisto de sentido en el futuro e incomprensibe para cualquiera que no lo haya vivido."

Accidentalmente, esta pregunta dolorosa entró en diálogo con otra que era su simétrica y con la que me encontré en la misma época, al final de un artículo sobre la literatura rumana de la posguerra escrito por otro amigo que vivía en París: "la literatura rumana encontró la fuerza de sobrevivir a la dictadura; iencontrará la de no decaer cuando ya no exista la coacción? Nadie puede responder a esta pregunta, pero debe ser planteada" (TLS, 19-25 de nero de 1990).

Hay que pagar un precio por desafiar a la tiranía (incluso por el sesgo de la literatura). A veces, los que lo pagaron, pagan otra vez más tarde un precio que no es desdeñable, por descubrir el sentido de la confrontación en una sociedad democrática. Pero tanto uno como otro tienen que ver con las premisas de la libertad, que es esencial a la humanidad, por más desconcertantes que puedan ser a veces estas contradicciones.

"La libertad es algo más complejo y más sutil que la violencia", escribió Thomas Mann. ${ }^{21}$ Los que se fueron al exilio, medio siglo después que el gran escritor alemán, confirman una vez más la verdad de estas palabras. ¿Serán confirmadas otra vez por los pueblos de Europa del Este recientemente liberados?

La diversidad de las opciones, los rigores de la competencia, la vulnerabilidad y el riesgo, las duras leyes del mercado y el estremecimiento de la aventura, los excesos y las inhibiciones que resultan del dinamismo productivo, quizás exagerado, de la democracia; éstos son sólo algunos de los aspectos de una sociedad libre.

Estamos conociendo el precio de la libertad después de haber conocido el de la tiranía. Y reafirmamos, por las heridas mismas hechas a nuestro destino, el valor de la libertad. Incluso cuando la libertad nos recuerda todo lo frágiles que pueden ser sus sutiles articulaciones, todo lo complejas y relativas que pueden ser las soluciones.

Muy especialmente en estos momentos, quizás.

${ }^{21}$ Extracto de una carta a Erika y Klaus Mann, de diciembre de 1938. 